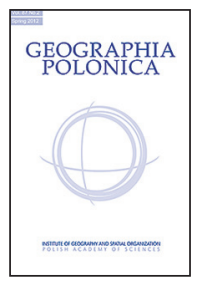

\title{
FROM WORDS TO ACTION: IMPROVING DRINKING WATER BEHAVIOUR IN THE URBAN ENVIRONMENT
}

\author{
Katarina Polajnar Horvat • Aleš Smrekar \\ Anton Melik Geographical Institute \\ Research Centre of the Slovenian Academy of Sciences and Arts \\ Novi trg 2, 1000 Ljubljana: Slovenia \\ e-mails: katarina.polajnar@zrc-sazu.si・ales.smrekar@zrc-sazu.si
}

\begin{abstract}
This article analyzes the impact of selected external and internal factors on environmental behaviour and the relationship between individuals' willingness to engage in environmentally friendly activity and their actual actions. Our model served as a framework for understanding the development of environmental awareness and the change of habits in favor of sustainability. The main variables included in the model were values, beliefs, norms, perceived environmental control, demographic variables, knowledge, intention, and behaviour. The results based on the example of Ljubljana indicate that environmental motives and knowledge are the factors predominantly influencing actual environmentally friendly habits. It is concluded that a bottom-up approach with selected social influence methods is the most appropriate.
\end{abstract}

\section{Key words}

environmental awareness $\cdot$ behavioural geography $\bullet$ behavioural factors $\bullet$ drinking water $\cdot$ sustainable development • Ljubljana

\section{Introduction}

Modern social behaviour is a result of industrial and mining development over the past two centuries. Over the last fifty years, people in the developed world have been enjoying a higher standard of living than at any other time in history, increasingly using goods and services that were not available in the past. Unfortunately, however, the ways in which these goods and services are produced, bought, and used have become the main sources of burdens on the environment (Giddens 2002). Thus, production and consumption often exceed the carrying capacity of the environment, although a healthy environment can be a basis for progress and prosperity. Households - a basic feature of modern domestic organization - and the people living in them are an important link in the consumption chain (Clift et al. 2013). On a daily basis, they direct the selection of services and the consumption of goods with their lifestyles, their values, and the way they think and act. Among 
these goods, water has a special place due to its value as a natural resource and its vulnerability as a landscape element of modern society, particularly in urban areas. Therefore, the natural geographic and socio-geographic characteristics of a given area have an impact on the state of the environment.

In recent times, very few people have never been exposed to information about environmental pollution and the necessity of protecting the environment. However, they usually do not consider their negative attitude towards the environment. Even more commonly, they attribute this to the general social mindset or to generally accepted behaviour in society (Malačič 2007). They have an alienated attitude towards the environment and often act in accordance with the principle of "There is no sense in doing my best to benefit the environment when others fail to do the same." They are not aware of their role and of importance of their actions, and even people that are environmentally aware often find themselves trapped in environmental apathy (Polič 2002). At the same time, people are often too short-term oriented to think about long-term consequences for the planet. As a result, they are generally insufficiently environmentally active. According to some studies (Smrekar 2011; Polajnar Horvat 2015), only one person out of five bothers to think about how to contribute to improving the quality of the environment.

Environmental habits are influenced by numerous factors emanating from within a person as well as from a person's narrower or wider social environment. People's social environment crucially influences and directs their lives. Research usually divides environmental behaviour factors into internal and external factors. Psychological factors are among the internal factors (Abrahamse 2007), whereas social factors are external. The latter rarely directly influence behaviour (Marentič Požarnik 2000). In geography, researchers mostly focus on studying the influence of external factors, whereas psychologists primarily study internal, psychological factors. Because there is no clear boundary between internal and external factors due to their interdependence and interweaving, the need for an interdisciplinary approach emerged.

Water is a vital resource, and its scarcity and contamination are among the main environmental problems and challenges humanity faces in the twenty-first century (Brown \& Flavin 1999). Thus, water conservation is one of the most important ecologically conscious activities and critical components to be modeled and developed for a sustainable way of life (Corral-Verdugo et al. 2003; Oiste 2014). It can be managed by changing people's habits and their lifestyle (Gardner \& Stern 2002; Vlek \& Steg 2007). Changes in human behaviour are necessary because technical efficiency gains resulting from water-efficient appliances and water-saving devices tend to be overtaken by growth in water consumption (Midden et al. 2007). In environmental behaviour, efforts have been made to study the factors of a number of environmentally friendly activities, such as reuse, recycling, and energy savings, among others (Garder \& Stern 2002; Abrahamse \& Steg 2011; Jekria \& Daud 2016). Despite the importance of water as a critical resource, relatively limited research has been carried out regarding the factors of water conservation habits. Moreover, when compared with policies related to household economy (e.g., energy use or waste management), this has not been given serious attention by the European Union. Not only in Slovenia, but also in the European Union in general, a conviction still prevails that there is a great abundance of highquality drinking water. As a consequence, water is still taken for granted and people do not tend to perceive it as something valuable (Polajnar Horvat 2015).

This study analyzes selected external and internal factors of water-related environmental behaviour and establishes correlations between these factors and environmental awareness, as well as the relationship between people's willingness to engage in environmentally friendly activity and their actual environmental behaviour. 


\section{Methods}

\section{Sample area}

With a population under 300,000, Ljubljana is among the smaller European capitals. Because a substantial part of the city is located above a large aquifer with an abundance of groundwater, constituting the most important water source for the Slovenian capital and the surrounding settlements, a set of (un)favorable natural and social circumstances has resulted in the fact that a sizeable part of the city that should have been strictly protected due to drinking water pumping stations has become a degraded landscape with numerous illegal dumpsites (Breg et al. 2007), illegal gardening (Jamnik et al. 2009), illegal extraction of water (Smrekar \& Kladnik, 2007) and gravel (Urbanc \& Breg, 2005), and inappropriate manure storage facilities (Kladnik et al. 2003). On the other hand, this area has fortunately been spared the suburbanization process. Furthermore, the City Municipality of Ljubljana is characterized by rapid growth in material wellbeing, which has been more intensive here than in other areas, resulting in corresponding increased household consumption for the past twenty years. The effects of extensive consumption are primarily felt in the excessive use of natural resources and rapid accumulation of waste, which significantly deteriorates the quality of the living environment and puts drinking water supplies at risk. Remediation, regeneration, and redevelopment of degraded areas are among the greatest challenges faced by spatial planners. However, thanks to growing environmental awareness, this is becoming increasingly feasible.

\section{The model of environmental awareness and environmental behaviour development}

The research on the role of social factors in the development of environmental awareness and changing environmental activity was carried out in two phases. In the first phase, based on theoretical and practical information obtained so far, we developed a model of factors that we believe influence the development of environmental awareness and behaviour. We primarily drew on demographic (sex, age, and education) and psychological (personal norms, subjective norms, beliefs, and perceived behavioural control) factors, actual control, and social influence methods that, according to theoretical findings, define an individual's environmental habits most holistically while also influencing it. The model served as a tool for interpreting answers to the questions from the empirical part of the study.

The second, empirical phase was comprised of an extensive survey conducted within the City Municipality of Ljubljana. It was used to determine the level of people's environmental awareness and the characteristics of their environmental behaviour. Four hundred eight personal interviews were conducted. The target population consisted of permanent residents of the City Municipality of Ljubljana; specifically, representatives of households at least fifteen years old. Because research on general environmental awareness and environmental behaviour fails to deliver appropriate results and the bases for further work, it no longer satisfies the needs of contemporary theory and practice (Žibert 2009). The difficulty encountered is the fact that people tend to act differently in different contexts. Therefore, researchers (e.g. Schlegelmilch et al. 1996; Follows \& Jobber 1999) propose studying more concrete activity. Research carried out so far (Hines et al. 1987; Kaiser \& Shimoda, 1999; Kollmuss \& Agyeman 2002; Abrahamse 2007) indicates that environmental habits can be recognized and predicted more successfully when directed behaviour is measured and studied instead of general behaviour. In studying the characteristics of environmental behaviour, we focused on studying water-related habits.

\section{Variables in the model of environmental awareness and environmental behaviour development}

In order to determine the influence of selected internal and external factors on the intention to engage in environmentally friendly 
behaviour, we conducted multi-variant linear regression analyses, to which we added factors by using the Enter method. In this way, we obtained insight into what proportion of variability of a selected dependent variable can be attributed to internal (psychological and cognitive) factors on the one hand and external (social) factors on the other.

The model developed served as a complex framework by which the course of the development of environmental awareness and behavioural change towards sustainability could be systematically explained. It can be an important tool for remediating the degraded environment as a result of inappropriate human activity. It is composed of selected behavioural theories as building blocks: Ajzen's theory of planned behaviour (1991), Stern's value-belief-norm theory (2000), and the knowledge deficit model (Schultz 2002), acting as factors and leading towards a certain activity directly or through behavioural intentions. It also includes demographic factors and selected social influence factors. The variables included in the model studied are presented below in greater detail.

Values were measured with ten qualityof-life indicators (equity and justice, peace, power and influence, ambition, wealth, reputation and fame, comfort and pleasure, joy of life, living in harmony with nature, and environmental protection), which were defined by using Schwartz's values scale (Schwartz 1992), and the findings of selected earlier research on the impact of values on environmental behaviour (De Groot \& Steg 2007; Steg et al. 2011). On the basis of a five-point Likert scale, survey participants ranked the importance of the quality-of-life indicator as a guiding principle in their lives. The higher it was ranked, the more important they found it to be in their lives. Our study of values was based on the assumption that values make up several common dimensions (Schwartz 1992) that can be singled out by using various multivariate analyses (Musek 1993, 2000). Thus, the data obtained pertaining to quality-of-life indicators were analyzed by using the principal component method, which resulted in four main components of values that were singled out.

Beliefs relating to the use of water in households were measured using a five-point Likert scale; furthermore, each of the five beliefs was composed of three subcategories. They were shaped on the basis of Stern's (2000) division of beliefs as defined in the value-belief-norm theory. Beliefs can be defined as a combination of individuals' awareness of the consequences of environmental engagement, awareness of their own responsibilities, and their beliefs regarding the reasonableness of environmental engagement. An individual's awareness of consequences was measured using the following statements: "The quantity of global water extraction is approaching the upper limits of available resources, which represents a great social problem" and "By saving water I can contribute to the preservation of valuable water resources". Awareness of one's responsibility for water-related problems was measured using the statements "I feel responsible for the worsening of waterrelated problems facing the world" and "I feel responsible for overexploitation of water resources for the needs of humanity", and the reasonableness of environmental engagement was measured using the statement "Households should save water". The reliability of the set of items composed of the variables studied and presented here was verified using Cronbach's alpha coefficient.

Norms, which were also measured using a five-point Likert scale, were studied from two perspectives. On the one hand, they relate to an individual's assessment of normative expectations of people that influence them and their willingness to take these opinions into account in their behaviour. These are the rules governing social activity. In this study, we named them subjective norms. On the other hand, norms are defined as an individual's feeling of duty to act in an environmentally friendly manner. They relate to an individual's perception of what is 'appropriate' in given circumstances and to an individual's self-appraisal of certain behaviour. We named these norms personal norms. Subjective norms were 
measured using two statements: "Members of my family and my friends think saving water is necessary" and "I entirely support the opinion of my family and friends regarding water management". Personal norms were measured using three statements: "I feel guilty if I use water excessively", "I feel morally obliged to reduce water consumption regardless of how other people use water", and "I feel better if I use less water". The reliability of the set of items composed of the variables presented here was verified using Cronbach's alpha coefficient.

Perceived behavioural control reflects individuals' opinion regarding their capability to engage in a certain behaviour. We measured it using a five-point Likert scale on the basis of three statements: "I know the ways to save water," "Reduced water consumption largely depends on me," and "I can reduce water consumption without a problem." The reliability of the set of items composed of the variables studied was verified using Cronbach's alpha coefficient.

We also included three demographic variables in the model: sex, age, and education level. The sex ratio of the sample was measured by using a nominal scale $(0=$ male, $1=$ female). Age structure was determined on the basis of four age groups on an ordinal scale $(1=18-34$ years, $2=35-54$ years, $3=55-64$ years, $4=65$ years and older). The highest education level achieved was measured on the basis of four categories on a nominal scale ( 1 = elementary, 2 = vocational (two- and three-year school), $3=$ secondary (four- and five-year school), $4=$ higher vocational, higher professional, or academic.

The knowledge variable was measured on the basis of five questions; answers to these questions were ranked into five categories with values from 1 to 5 in accordance with their correctness. Answers differing from the correct answer by up to $20 \%$ were ranked in the fifth category, answers differing by $21-40 \%$ were ranked in the fourth category, answers differing by $41-60 \%$ were ranked in the third category, answers differing by $61-80 \%$ were ranked in the second category, and answers that differed by $80 \%$ or more were ranked in the first category. The following questions were used to determine the level of knowledge: "What is the average daily consumption of water per person?"; "How much water is wasted if we leave the faucet running while brushing our teeth?"; "How much water is lost in one day if one drop per second drips from the faucet?"; "How much water do we use in five minutes of uninterrupted showering?"; and "How much water do we use when bathing?". The results of individual variables were added up and the sum obtained was used as a numeric variable.

Intention to engage in environmentally friendly behaviour was measured by verifying an individual's willingness to act in a certain way. We measured it using a five-point Likert scale on the basis of two statements: "I am willing to save water over the next six months" and "I will save water over the next six months." The reliability of the set of items composed of both variables studied was verified using Cronbach's alpha coefficient.

The behaviour index measures the level of actual environmental behaviour. It was measured with a variable obtained on the basis of values of the following five variables:

- The variable of actually expressed past habits related to saving water;

- The variable of performing acts related to water use in a household obtained on the basis of variables defining actual water use. An example of such a variable is answering the following question: "How often do you leave the faucet running while you brush your teeth?";

- The variable of performing six acts related to saving water, such as answering the question: "Over the past six months, have you ever checked your home for water leaks?";

- The variable of willingness to join the Healthy Drinking Water Foundation and contribute $€ 0.50$ per month for preserving or improving of the quality of drinking water, obtained by answering the question "Are you willing to support the Healthy Drinking Water Foundation with a monthly contribution of $€ 0.50$ ?"; 
- The variable of expressing willingness to join the ecological group and actually joining the ecological group.

Finally, we added up the values of all five selected variables and obtained a common numeric variable, which, as mentioned above, we named the behaviour index. Its lowest and highest values are 0 and 9 .

\section{Environmental behaviour factors}

Increasingly in-depth knowledge and, consequently, understanding of the causes deterring people from environmentally friendly habits is important for policymakers and those that make decisions about activities affecting the environment, as well as for researchers trying to find solutions for environmental problems on the basis of behavioural changes.

The theory of planned behaviour (Ajzen 1991 ) is one of the best-established theories explaining environmental activity. It emphasizes perceived individual benefits, constraints. and perceived social pressures in relation to behavioural choices (Abrahamse 2007). According to the theory, the immediate antecedent to behaviour is the behavioural intention to perform it. This intention is an indication of an individual's willingness to perform a given act. It is based on the attitude towards the activity, the subjective norm, and perceived behavioural control, with each predictor weighted for its importance in relation to the activity and population of interest (Ajzen 1991). When the theory of planned behaviour was published (1991), Ajzen already emphasized it was open to improvement. Many studies were carried out in which researchers added various factors to the theory to improve the effectiveness of the original theory or its ability to predict behaviour (Conner \& Armitage 1998; Kaiser 2006; Collins \& Mullan 2011).

In this study, our focus was to enhance the original theory to include moral and normative behavioural dimensions; specifically, personal norms, values, and beliefs. In doing this, we focused on beliefs that are based on the awareness of consequences and the awareness of responsibility. Namely, in their research, many contemporary authors (Stern et al. 1999; Bamberg \& Schmidt 2003; Gifford et al. 2011) confirm the conviction that moral and normative dimensions have a great influence on environmentally friendly habits, which has not been given direct attention by the theory of planned behaviour. Furthermore, we also enhanced the theory of planned behaviour by including the knowledge deficit model (Schultz 2002), which is based on the assumption that knowledge is a decisive factor of change in environmental activity. The main goal of enhancing the original theory to include the two additional elements was to more effectively explain the intentions and activities studied, with the intention to contribute to shaping a more useful behaviour planning model.

In more important behaviour studies (Van der Putte 1991; Godin \& Kok 1996; Armitage \& Connor 2001) that were based on the theory of planned behaviour (Ajzen 1991), subjective norms proved to be the weakest link for environmental behaviour intention as well as for actual activity. Thus, in many studies (e.g. Harland et al. 1999), perceived behavioural control and (even more so) beliefs exhibit substantial prevalence over the normative component. Although one of the reasons for this may be that the normative component is less important in the intention to engage in environmentally friendly behaviour as well as in the actual activity itself, it is not the only reason. One of them may be that in the theory of planned behaviour subjective norms relate exclusively to the acceptance or non-acceptance of a certain act by important influential people, but they do not relate to an individual's own moral feelings.

The early concept of the model of reasoned action (Fishbein 1967) was based on Dulany's (1968) theory of propositional control; Fishbein's theory included a variable that measured beliefs and two normative variables, one covering a personal normative component and the other a social component. He assumed that the influence of both (personal and social) normative components on a behavioural intention depends on an individual's 
motivation to be subjected to them. However, this assumption proved to be unsuccessful, particularly in studying the influence of personal norms on intention and habits. Therefore, Ajzen and Fishbein (1969) eliminated this component in further analyses and model developments. Since then, the normative component of the model has been composed solely of subjective norms, by which a personal normative component is excluded from behaviour prediction.

As research on environmental behaviour was expanding, researchers were increasingly pointing out that actions are not influenced exclusively by external social norms, but instead by an individual's personal internal feelings and moral responsibility as well. Personal norms were largely dealt with by Schwartz (1968 and 1977). In the norm activation theory (Schwartz 1968), he defined them as one's expectations based on internalized values. They are the so-called feelings of personal moral obligation leading to performance of certain behaviour (Schwartz 1977), which takes place as they are activated. It happens as individuals becomes aware of positive consequences of their actions for others while attributing at least some credit for that to themselves (Schwartz \& Howard 1984).

One advantage of this theoretical framework is that it clearly distinguishes between personal norms and other behavioural factors. In this way, Schwartz (1977) overcame the issue Ajzen and Fishbein (1970) had to deal with: a strong correlation between primary personal norms and an intention. Namely, a feeling of personal moral obligation, which is expressed through the activation of norms, can be prevented before the emergence of an intention; for example, by denying the seriousness of the consequences of certain action. In Schwartz's model as well, personal norms are clearly separated from behavioural beliefs. As opposed to other concepts, in which assessment is based on a combination of material, social, and psychological perspectives, personal norms in the model are focused explicitly on the assessment of one's moral perspectives. Moreover, personal norms, although influenced by social expectations within the socialization process, are clearly distinguished from social norms. Antecedents to personal norms (i.e., expectations, sanctions, and obligations) are anchored in an individual, whereas antecedents to social norms are anchored in a society (Schwartz \& Howard 1984; Harland et al. 1999).

In several studies, personal norms as an addition to existing factors of the theory of planned behaviour (1991) proved to be important in predicting environmental behaviour. The role of personal norms in the theory was also studied by Parker, Manstead, and Stradling (1995), who realized that, by adding personal norms, the share of explained variance of the dependent behaviour variable increased significantly. Similar results were also obtained by researchers studying some other types of activity; for example, willingness to donate blood and bone marrow (Schwartz \& Tessler 1972), drinking alcoholic beverages in public places (Budd \& Spencer 1985), insincere behaviour (Beck \& Ajzen 1991), and the use of contraception (Boyd \& Wandersman 1991).

One of the shortcomings of environmental behaviour studies based on general behavioural theory or the theory of planned behaviour (1991) is that they focused exclusively on studying general beliefs about the environment, whereas they gave no attention to the role of environmental concern in environmental behaviour, which was given a considerable amount of attention by Stern (2000) in his value-belief-norm theory. Research conducted so far on predicting environmental behaviour (Steg \& Vlek 1997; Garvill 1999) has shown a considerable importance of environmental concern measured by using the concept of the awareness of consequences and moral responsibility in relation to environmental behaviour. Thus, it is reasonable to add the aspect of environmental concern, particularly the concept of awareness of consequences and moral responsibility, to general beliefs in the theory of planned behaviour, by which the gap in the theory of planned behaviour (1991) should be filled. 
Apart from personal norms and environmental concern, values - which serve as guiding principles in people's lives - are an important anticipator of people's actions (Schwartz 1992). It was established that values directly and indirectly affect habits, which makes them a particularly important factor (Schwartz 1992; De Groot \& Steg 2008; Crompton $\&$ Kasser 2009). Stern's division of values in the value-belief-norm theory (Stern 2000), which is based on Schwartz's model of values (1977), distinguishes between individual values, which are manifested in concern for one's self-realization or fulfilment of one's interests, and collective values, which are manifested in concern for the fulfilment of interests of the entire society. Individuals with a more positive attitude towards collective values largely favor environmental protection, their attitude towards the environment is positive, and they largely act accordingly (Stern et al. 1998; Dietz et al. 2005). Within collective values, researchers (Steg et al. 2005; DeGroot \& Steg 2008, 2010; Steg et al. 2014) distinguish between two fundamental types of values: altruistic and biospheric. Biospheric values are manifested in expressing concern regarding the quality of nature and the environment, whereas altruistic values are characterized by expressing concern regarding the wellbeing of all people. Although both types of values are closely linked with an individual's environmental attitude, biospheric values show a greater level of interrelatedness (Steg et al. 2005; DeGroot \& Steg 2007, 2008). Within individual values, researchers define egoistic values that are manifested in expressing concern about one's own benefit and minimization of expenses. Their correlation with an individual's environmental attitude is negative (Steg et al. 2005; De Groot \& Steg 2008, 2010). Researchers have recently discovered that individual values are not only comprised of egoistic values, but also include hedonic values. These have proven to be an important factor of predicting environmental behaviour (Steg et al. 2014). Sometimes individuals do not act in an environmentally friendly manner even if they would benefit from doing so.
According to researchers, such an attitude can be attributed to the fact that an individual may also be driven by personal benefits that do not emanate from egoistic values but, instead, are grouped under hedonic values, such as comfort and pleasure. Such an example would be taking shorter showers: on the one hand, this reduces water consumption and improves the quality of the environment, and on the other it obviously reduces an individual's comfort. Thus, in environmental research, researchers propose the division of values into individual values, which manifest themselves in egoistic and hedonic values, and collective values, which are manifested in biospheric and altruistic values (Steg et al. 2014). This division was also used for development of our model of predicting environmental behaviour.

One of the shortcomings of the research that was based on the theory of planned behaviour (1991) is the absence of the separate component of an individual's knowledge, which has proven to be as important a factor of engaging in environmentally friendly activities (Hines et al. 1987; Schultz 2002). Namely, before performing a certain act, individuals must be well informed about the causes and consequences as well as the course of their action. Research (Vining \& Ebreo 1990; Gamba \& Oskamp 1994) has also shown that the education level achieved also has a significant influence on whether or not waste is separated in households. Therefore, in addition to expanding the theory of planned behaviour (1991) by adding a normative component, it is also reasonable to add knowledge (in research carried out so far, it has only been included within beliefs) as a separate component.

Thus, the initially proposed model of the development of environmentally friendly behaviour is composed of selected behavioural theories (Ajzen's theory of planned behaviour, 1991; Stern's value-belief-norm theory; 2000) as main building blocks and knowledge as an essential component of the knowledge deficit model (Schultz 2002) that lead to environmentally friendly behaviour either through behavioural intentions or directly, and are interdependent in various directions (Fig. 1). 


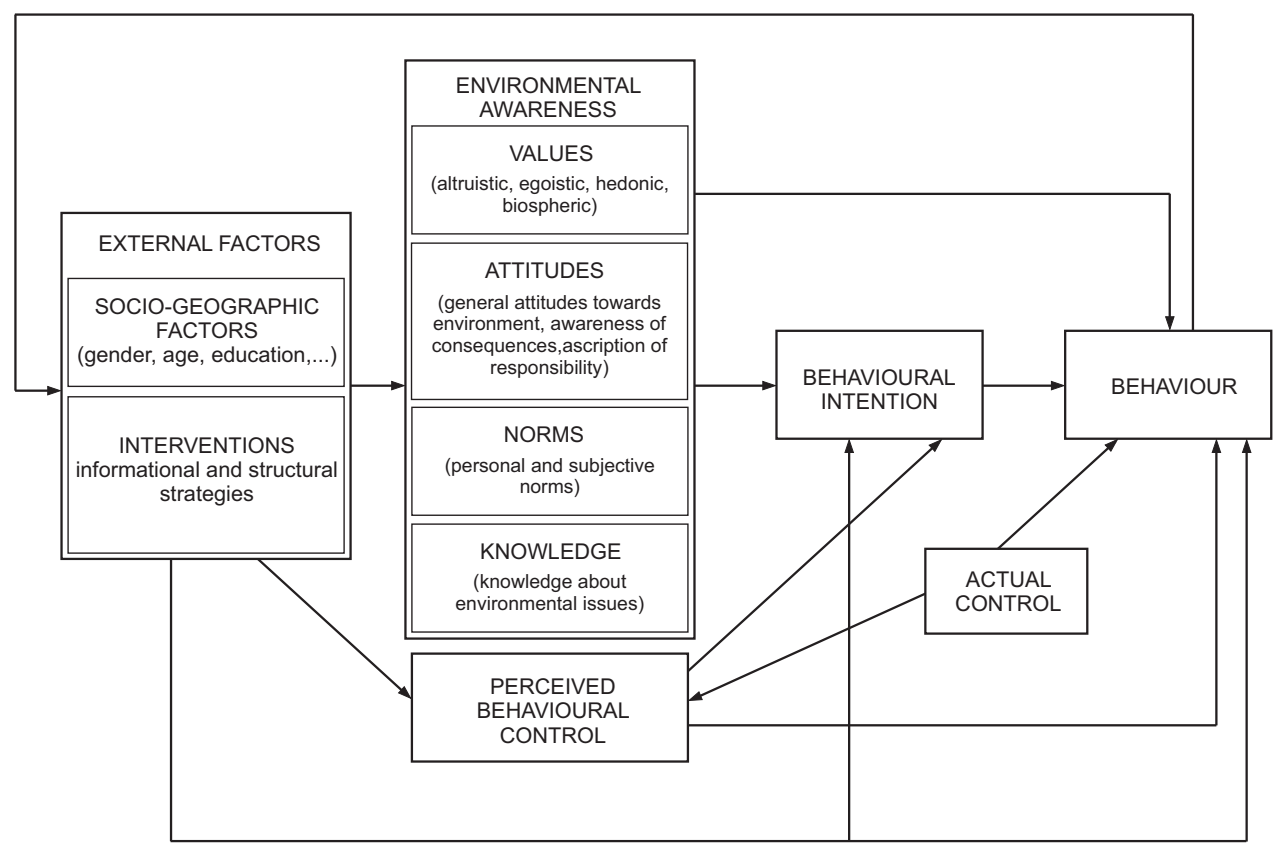

Figure 1. The theoretical model of environmental awareness and behavioural change Source: based on Ajzen (1991), Stern (2000), Schultz (2002).

\section{Results and discussion}

In the first regression model, the intention to engage in environmentally friendly activity was used as a dependent variable, whereas the following internal factors were used as independent variables: beliefs, personal and subjective norms, perceived behavioural control, four types of values (biospheric, egoistic, hedonic, and altruistic), and knowledge. In addition, the demographic variables of sex, age, and education and the variable of actual control were included in the first model.

The model proved to be successful and statistically significant at the $p<0.001$ level. The $R^{2}$ value is 0.62 , which means that $62 \%$ of variability of the dependent variable 'intention' can be attributed to differences in independent variables. The model is statistically successful, and the statistical significance of the $F$-test is high $(F=33.44)$. The intention to engage in environmentally friendly behaviour is influenced the most by psychological variables, as follows: perceived behaviour control $(\beta=0.321, p<0.001)$, beliefs $(\beta=0.268$, $p<0.001)$, and subjective norms $(\beta=0.223$, $p<0.001)$. In addition, intention is statistically significantly, but to a lesser degree, influenced by personal norms $(\beta=0.135, p<0.05)$. Willingness to engage in environmentally friendly behaviour is not influenced by any of the values studied; neither is it influenced by the demographic variables studied, knowledge, or actual control (see Tab. 1; Polajnar Horvat 2010).

The motivation of Ljubljana residents to engage in environmentally friendly behaviour is influenced not so much by external (i.e., social factors) but more by internal factors. To a greater extent, it is influenced by the conviction of one's effectiveness, the feeling of one's ability to engage in environmentally friendly behaviour, and the perception of its difficulty. Therefore, individuals are significantly motivated by a feeling that they are capable of engaging in environmentally friendly behaviour. The more they believe 
Table 1. Results of multiple regression analysis for the dependent variable 'intention' in personal interviews

\begin{tabular}{|l|c|c|c|}
\hline \multirow{2}{*}{ Model } & $\begin{array}{c}\text { Standardised } \\
\text { coefficients }\end{array}$ & $\mathrm{p}$ \\
\cline { 2 - 3 } & Beta & $\mathrm{t}$ & 0.335 \\
\cline { 2 - 3 } (constant) & & -0.965 & 0.000 \\
beliefs & 0.268 & 5.536 & 0.000 \\
subjective norms & 0.223 & 3.601 & 0.000 \\
perceived behavioural control & 0.321 & 6.017 & 0.035 \\
personal norms & 0.135 & 2.119 & 0.276 \\
egoistic values & 0.044 & 1.092 & 0.914 \\
altruistic values & 0.005 & 0.108 & 0.852 \\
biospheric values & -0.009 & -0.187 & 0.412 \\
hedonic values & 0.036 & 0.822 & 0.087 \\
sex & 0.068 & 1.720 & 0.475 \\
age & -0.029 & -0.716 & 0.493 \\
education & 0.027 & 0.687 & 0.402 \\
actual control & -0.033 & -0.840 & 0.179 \\
knowledge & 0.054 & 1.347 & \\
\hline
\end{tabular}

in their capabilities, the greater their motivation or willingness to engage in such activity. Aside from perceived behavioural control, individuals are motivated by their conviction of the reasonableness of engaging in such activity and their awareness of the consequences and responsibilities of such activity. The more their beliefs favor engaging in environmentally friendly behaviour, the stronger their willingness to engage in it. Individuals are also rather motivated by considering what kind of habits are expected from them by influential people (i.e., family members and friends), and, of course, their willingness to submit to their opinion. The higher an individual's subjective norms, the more the motivation depends on the prevailing opinion of influential people. The more they are convinced their habits should be environmentally friendly, the greater their willingness to engage in such activity. The motivation is also influenced by personal norms; that is, a feeling of duty to engage in environmentally friendly behaviour in given circumstances. Thus, the more individuals feel obliged to act in accordance with social rules (i.e., in the 'right way'), the stronger their motivation to actually behave in such a way. Interestingly, actual control (in our case, this was established by measuring water consumption in households) does not affect the motivation for being environmentally friendly.

In the second regression model, our goal was to determine the influence of the independent variables studied on the dependent variable 'behaviour'. The summary of the regression model is statistically significant at $p<0.001$. The $R^{2}$ value is 0.357 , which means that $35.7 \%$ of variability of the dependent variable can be attributed to differences in independent variables. The $F$ value is 10.9 .

Among independent variables that simultaneously entered the regression model, engaging in environmentally friendly behaviour is predominantly influenced by personal norms $(\beta=0.246, p<0.001)$, education level $(\beta=0.194, p<0.001)$, knowledge $(\beta=0.120$, $p<0.05)$, and values, among which egoistic values have an influence in a negative direction $(\beta=-0.106, p<0.05)$ and biospheric values in a positive direction $(\beta=0.112, p<0.05)$. In the case of other independent variables, the significance of coefficients is $p>0.05$, which 
means that their influence is statistically insignificant (Tab. 2; Polajnar Horvat 2010).

Therefore, the actual environmentally friendly behaviour of Ljubljana residents largely depends on their own perception of their acts and self-assessment of their habits; environmentally friendly behaviour is exercised by those that feel greater moral responsibility to engage in it and have a deeper feeling of guilt when they fail to do it. Among psychological factors, values also influence the actual activity. People with a positive attitude towards biospheric values - which are manifested, for example, in care for the environment and nature - are more friendly towards the environment. On the other hand, they have a distinctly negative attitude towards egoistic values, which are manifested in the desire for power, influence, wealth, reputation, and fame. Among the social factors studied, the level of education has a rather strong influence on actual behaviour as well. Namely, people with a higher level of education engage in environmentally friendly behaviour more often. Knowledge proved to be an important indicator of behaviour, whereby people with more knowledge exercise greater care for the environment, are more thrifty in everyday household chores, and are also more willing to donate money for environmental protection and to actively engage in it. Actual control does not influence the motivation for environmentally friendly behaviour, which is also true in the case of its influence on actual activity. Therefore, the manner of paying water bills did not prove to be an important factor, neither in motivation for environmentally friendly behaviour nor in actual environmentally friendly behaviour.

The results obtained show differences between the influence of independent variables on the intention or motivation for environmentally friendly behaviour on the one hand, and actual activity on the other. The only independent factor with statistically significant influence on both dependent variables is personal norms. On the other hand, beliefs, perceived behavioural control, and subjective norms are a strong motivator of environmentally friendly behaviour, but their influence dissipates somewhere during the transition from intention to actual activity. This indicates

Table 2. Results of multiple regression analysis for the dependent variable 'behaviour' in personal interviews

\begin{tabular}{|c|c|c|c|}
\hline \multirow[t]{2}{*}{ Model } & $\begin{array}{l}\text { Standardised } \\
\text { coefficients }\end{array}$ & \multirow[t]{2}{*}{$t$} & \multirow[t]{2}{*}{$p$} \\
\hline & Beta & & \\
\hline (constant) & & -0.649 & 0.517 \\
\hline perceived behavioural control & 0.127 & 1.825 & 0.069 \\
\hline personal norms & 0.246 & 3.010 & 0.001 \\
\hline subjective norms & 0.048 & 0.750 & 0.454 \\
\hline beliefs & 0.095 & 1.143 & 0.254 \\
\hline egoistic values & -0.106 & -1.976 & 0.049 \\
\hline altruistic values & 0.058 & 1.036 & 0.301 \\
\hline biospheric values & 0.112 & 1.439 & 0.050 \\
\hline hedonic values & -0.059 & -1.041 & 0.299 \\
\hline $\operatorname{sex}$ & 0.006 & 0.117 & 0.907 \\
\hline age & -0.023 & -0.426 & 0.671 \\
\hline education & 0.194 & 3.711 & 0.000 \\
\hline actual control & -0.093 & -1.778 & 0.077 \\
\hline knowledge & 0.120 & 2.252 & 0.025 \\
\hline
\end{tabular}


that, in principle, quite a few people support environmental protection and corresponding behaviour, which they also feel capable of, and they also highly value the opinion and support of their close friends and relatives in relation to their habits. However, when they have an opportunity to participate, their zeal quickly fades, which means they often fail to act in accordance with their good intentions. Their activity is also influenced by biospheric values in a positive direction and egoistic values in a negative direction. Participants with more strongly expressed biospheric values actually act in an environmentally more friendly manner.

Aside from the psychological factors studied, actions are also influenced by social factors, particularly by the level of education and by cognitive factors such as knowledge, which somehow confirms findings from similar research (Brandon \& Lewis 1999; Gatersleben et al. 2002; Abrahamse 2007). Namely, participants with a higher level of education and better knowledge of the subject matter studied act in an environmentally friendlier manner.

Therefore, environmental motives (which are reflected in the factors from Stern's value-belief-norm theory, 1991) and knowledge have a stronger influence on actual environmentally friendly behaviour than on intention, in which individual motives (factors of Ajzen's theory of planned behaviour) prevail. The reason for people's engagement in environmentally friendly behaviour is not so much their pursuit of material wellbeing and comfort, but their desire for environmental conservation, whereas their intention is also influenced by other factors not directly related to the environment.

Thus, actual control has no influence on either motivation or actions, which is surprising considering that Ljubljana residents, who do not pay water bills based on actual consumption, are rather critical of such limitations at the level of principle. Perceived behavioural control (i.e., subjective perception of control or the confidence of survey participants in their self-effectiveness) proved to be a more important behavioural factor than actual control, which has already been shown by many authors (e.g., Bandura 1986, 1997; Endler et al. 1999). This is confirmed by the fact that participants that actually save water are less concerned with its payment in accordance with their actual consumption because their water saving arises from actual environmental motives.

Subjective norms proved to be an important factor in the intention to engage in environmentally friendly behaviour; however, their influence fades in actual activity. One reason for this can be that those that actually act in an environmentally friendly manner are less concerned about the opinions of people that influence them. Their actions are more in accordance with their beliefs, but still within general socially accepted norms.

The results show that, among social factors, education level and knowledge (which are also expressed in bridging the gap between motivation and actual activity) are those primarily influencing actual activity. One reason for the intention or motivation to engage in environmentally friendly behaviour to be dependent solely on psychological variables may be the fact that it is considered a conscious decision (Abrahamse 2007). Namely, people consciously decide whether they are willing to act in an environmentally friendly manner or not, whereas their actual activity, as the results indicate, is not only influenced by their conscience, but by external factors as well - which, in our case, are primarily education level and knowledge.

\section{Conclusion}

This article presents the role of social factors in the development of environmental awareness and the shaping of environmentally friendly behaviour. The modern way of life, which is becoming increasingly materially demanding, and the anthropocentric worldview are intensifying people's interactions with the environment and increasingly transforming it. The environment has often been degraded by humans, which is why people's mentality, awareness, and behaviour are the key factors 
in burdening the environment as well as remediation of environmental burdens.

The base model of environmental behaviour development - which combines factors from Ajzen's theory of planned behaviour (1991), factors from Stern's value-belief-norm theory (2000), knowledge, and external factors - proved to be partially applicable. In particular, actual control proved irrelevant; we established that its role is assumed by perceived behavioural control; that is, a person's subjective perception of control over behaviour or a feeling of one's capability to engage in environmentally friendly behaviour. Other components studied proved to be appropriate and significant; differences mostly occur in their interconnectedness, with intention on the one hand and activity itself on the other. We established that willingness to engage in environmentally friendly behaviour is more distinctly defined by internal, psychological factors of environmental behaviour, but it is also determined by external, social factors, particularly education level and knowledge, which in a way confirms the findings of similar research carried out to date (Midden \& Ritzema 1986; Brandon \& Lewis 1993; Gatersleben et al. 2002; Abrahamse 2007). Among internal factors, personal norms (i.e., an individual's normative component) proved to be an equally strong drive of an individual's environmental awareness and habits. Environmentally more active individuals feel greater moral responsibility and have a stronger feeling of guilt if they do not behave in accordance with the laws of the environment. At the same time, it turned out that willingness to engage in environmentally friendly behaviour is influenced not so much by environmental motives but more by individual ones (particularly by factors from Ajzen's theory of planned behaviour), whereas actual activity is more significantly influenced by environmental motives (which are reflected in the factors from Stern's value-belief-norm theory).

Because the environmental crisis can also be characterized as a crisis of morality, it is no coincidence that, aside from a feeling of guilt, personal morality proved to be an equally important factor in actual environmental behaviour. Assuming one's own moral responsibility for the way one treats the environment is an elementary condition for actual actions.

One of the appropriate manners of transitioning to sustainable management of natural resources or to environmentally friendly behaviour is the approach that includes selected methods of social influence and is based on the 'bottom-up' principle; that is, on the inclusion of an individual from the beginning, through the "small steps policy." Introducing social influence methods into the education system (i.e., their incorporation into curricula) is certainly an appropriate way. With directed information, education, and other methods of social influence based on a practical approach, it is possible to achieve better understanding and increased awareness, which certainly also leads to appropriate shifts towards engaging in environmentally friendly behaviour. Because young people are the most open-minded in accepting changes, they are certainly the most effective medium for transferring such ideas and related habits to older generations.

Editors' note:

Unless otherwise stated, the sources of tables and figures are the authors', on the basis of their own research. 


\section{References}

ABRAHAMSE W., 2007. Energy conservation through behavioral change: Examining the effectiveness of a tailor made approach. Groningen: Rijksuniversiteit Groningen [PhD thesis].

Abrahamse W., Steg L., 2011. Factors related to household energy use and intention to reduce it: The role of psychological and sociodemographic variables. Human Ecology Review, vol. 18 , no. 1, pp. 30-40.

Auzen I., 1991. The theory of planned behaviour. Organizational Behaviour and Human Decision Processes, vol. 50, no. 2, pp. 179-211.

Auzen I., FishbeIn M., 1969. The prediction of behavioural intentions in a choice situation. Journal of Experimental Social Psychology, vol. 5, no. 4, pp. 400-416.

Auzen I., Fishbein M., 1970. The prediction of behaviour from attitudinal and normative variables. Journal of Experimental Social Psychology, vol. 6, no. 4, pp. 466-487.

Armitage C.J., Conner M., 2001. Social cognitive determinants of blood donation. Journal of Applied Social Psychology, vol. 31, no. 7, pp. 1431-1457.

BAMBERG S., SCHMIDT S., 2003. Incentives, morality or habit? Predicting students ' car use for university routes with the models of Ajzen, Schwartz and Triandis. Environment and Behaviour, vol. 35, no. 2, pp. 264-285.

BANDURA A., 1986. Social foundations of thought and action: A social cognitive theory. New York: Prentice Hall.

BANDURA A., 1997. Self-efficacy: The exercise of control. New York: W.H. Freeman.

BeCK L., Auzen I., 1991. Predicting dishonest actions using the theory of planned behaviour. Journal of Research in Personality, vol. 25, no. 3, pp. 285-301.

Boyd B., Wandersman A., 1991. Predicting undergraduate condom use with the Fishbein and Ajzen and the Triandis attitude-behaviour models: Implications for public-health interventions. Journal of Applied Social Psychology, vol. 21, no. 22, pp. 1810-1830.

Brandon G., Lewis A., 1999. Reducing household energy consumption: A qualitative and quantitative field study. Journal of Environmental Psychology, vol. 19, pp. 75-85.
Breg M., Kladnik D., Smrekar A., 2007. Dumping sites in the Ljubljansko polje water protection area, the primary source of Ljubljana's drinking water. Acta Geographica Slovenica, vol. 47, no. 1, pp. 73-103.

Brown L.R., FlaVIN C., 1999. A new economy for a new century [in:] State of the world 2007: Our urban future: State of the World. A Worldwatch Institute Report on Progress Toward a Sustainable Society, New York: W.W. Norton \& Company, pp. 3-21.

Budd R.J., Spencer C.P., 1985. Exploring the role of personal normative beliefs in the theory of reasoned action: The problem of discriminating between alternative path models. European Journal of Social Psychology, vol. 15, no. 3, pp. 299-313.

Clift R., SIM S., SinCLAIR P., 2013. Sustainable consumption and production: Quality, luxury and supply chain equity [in:] I.S. Jawahir, S.K. Sikdar, Y. Huang (eds.), Treatise on sustainability science and engineering, Amsterdam: Springer.

Coluins A., Mullan B., 2011. An extension of the theory of planned behavior to predict immediate hedonic behaviors and distal benefit behaviors. Food Quality and Preference, vol. 22, no. 7, pp. 638-646.

Conner M., Armitage C.J., 1998. Extending the theory of planned behaviour: A review and avenues for further research. Journal of Applied Social Psychology, vol. 28, no. 15, pp. 1429-1464.

Corral-Verdugo V., Bechtel R.B., Fraijo-Sing B., 2003. Environmental beliefs and water conservation: An empirical study. Journal of Environmental Psychology, vol. 23, no. 3, pp. 247-257.

Crompton T., Kasser T., 2009. Meeting environmental challenges: The role of human identity. Surrey: Green Books Ltd.

De Groot J.I.M., Steg L., 2007. Value orientations and environmental beliefs in five countries: Validity of an instrument to measure egoistic, altruistic and biospheric value orientations. Journal of Cross-Cultural Psychology, vol. 38, no. 3, pp. 318-332.

De Groot J.I.M., Steg L., 2008. Value orientations to explain environmental attitudes and beliefs: How to measure egoistic, altruistic and biospheric value orientations. Environment and Behaviour, vol. 40, no. 3, pp. 330-354.

De Groot J.I.M., Steg L., 2010. Relationships between value orientations, self-determined motivational types and pro-environmental behavioural 
intentions. Journal of Environmental Psychology, vol. 30, no. 4, pp. 368-378.

Dietz T., Fitzgerald A., Shwom R., 2005. Environmental values. Annual Review of Environment and Resources, vol. 30, pp. 335-372.

Dulany D.E., 1968. Awareness, rules, and propositional control: A confrontation with S-R behaviour theory [in:] T. Dixon, D. Horton (eds.), Verbal behavioural and general behaviour theory, pp. 340-387. New York: Prentice-Hall.

Endler N.S., Macrodimitris S.D., Kocovski N.L., 1999. Controllability in cognitive and interpersonal tasks: Is control good for you?. Personality and Individual Differences, vol. 29, no. 5, pp. 951-962.

FISHBEIN M., 1967. Attitude and the prediction of behaviour [in:] M. Fishbein (eds.), Readings in attitude theory and measurement, pp. 477-492. New York: Wiley.

Follows S.B., JobBeR D., 1999. Environmentally responsible purchase behaviour: A test of a consumer model. European Journal of Marketing, vol. 34, no. 5-6, pp. 723-746.

Gamba R., Oskamp S., 1994. Factors influencing community residents participation in commingled curbside recycling programs. Environment and Behaviour, vol. 26, no. 5, pp. 587-612.

Gardner G.T., Stern P.C., 2002. Environmental problems and human behaviour. Boston: Pearson Custom Publishing.

GARVILL J., 1999. Choice of transportation mode: Factors influencing drivers' willingness to reduce personal car use and support car regulations [in:] M. Foddy, M. Smithson, S. Schneider, M. Hogg (eds.), Resolving social dilemmas: Dynamics, structural, and intergroup aspects, Philadelphia: Psychological Press, pp. 263-280.

Gatersleben B., Steg L., Vlek C., 2002. Measurment and determinants of environmentally significant consumer behaviour. Environment and Behaviour, vol. 34, no. 3, pp. 335-362.

Giddens A., 2002. Runway world: How globalization is reshaping our lives. London: Profile Books.

GifFord R., Steg L., Reser J.P., 2011. Environmental psychology [in:] P.R. Martin, F.M. Cheung, M.C. Knowles, M. Kyrios, L. Littlefield, J.B. Overmier (eds.), The IAAP handbook of applied psychology, Hoboken: Blackwell Publishing Ltd., pp. 440-470.

GodIN G., KoK G., 1996. The theory of planned behaviour: A review of its applications to health-related behaviours. American Journal of Health Promotion, vol. 11, no. 2, pp. 87-98.

Harland P., StaAts H., Wilke H.A.M., 1999. Explaining proenvironmental intention and behaviour by personal norms and the theory of planned behaviour. Journal of Applied Social Psychology, vol. 29, no. 12, pp. 2505-2528.

Hines J.M., Hungerford H.R., TOMera A.N., 1987. Analysis and synthesis of research on responsible environmental behaviour: A metaanalysis. Journal of Environmental Education, vol. 18, no. 2, pp. 1-8.

Jamnik B., SMrekAR A., VRŠČAu B., 2009. Vrtičkarstvo v Ljubljani. Geografija Slovenije, 21, Ljubljana: Založba ZRC.

Jekria N., Daud S., 2016. Environmental concern and recycling behavior. Procedia Economics and Finance, vol. 38, no. 2, pp. 183-208.

KAISER F.G., 2006. A moral extention of the theory of planned behaviour: Norms and anticipated feelings of regret in conservationism. Personality and Individual Differences, vol. 41, no. 1, pp. 71-81.

KaIser F.G., ShimOda T.A., 1999. Responsibility as a predictor of ecological behaviour. Journal of Environmental Psychology, vol. 19, no. 3, pp. 243-253.

Kladnik D., Rejec Brancel I., Smrekar A., FranTAR P., SAJKO I., 2003. Dung installations as dangerous point sources burdening the groundwater of Ljubljansko polje. Acta Geographica Slovenica, vol. 43, no. 2, pp. 121-139.

Kollmuss A., Agyeman J., 2002. Mind the gap: Why do people act environmentally and what are the barriers to pro-environmental behaviour? Environmental Education Research, vol. 8, no. 3, pp. 239-260.

MaLAČlč E., 2007. Oblikovanje ekološko ozaveščenega posameznika in vpliv njegovih ukrepov na okolje in družbo. Ljubljana: University of Ljubljana [Bachelor's thesis].

Marentič-PožArnik B., 2000. Psihologija učenja in pouka: temeljna spoznanja in primeri iz prakse. Ljubljana: DZS.

Midden C.J.H., Kaiser F.G., McCalley L.T., 2007. Technology's four roles in understanding individuals' conservation of natural resources. Journal of Social Issues, vol. 63, no. 1, pp. 155-174.

Midden C.J., Ritzema B.S., 1986. The meaning of normative processes for energy conservation. 
Journal of Economic Psychology, vol. 4, no. 1-2, pp. 37-55.

MUSEK J., 1993. Osebnost in vrednote. Ljubljana: Educy.

MusEk J., 2000. Nova psihološka teorija vrednot. Ljubljana: Educy.

OıșTE A.M., 2014. Groundwater quality assessment in urban environment. International Journal of Environmental Science and Technology, vol. 11, no. 7, pp. 2095-2102.

Oskamp S., Harrington M.J., Edwards T.C., Sherwood D.L., OKUDA S.M., Swanson D.C., 1991. Factors influencing household recycling behavior. Environment and Behavior, vol. 23, no. 4, pp. 494-519.

Parker D., Manstead A.S.R., Stradling S.G., 1995. Extending the theory of planned behaviour: The role of personal norm. British Journal of Social Psychology, vol. 34, no. 2, pp. 127-138.

Polaunar Horvat K., 2010. Survey on drinking water behavior in the urban environment. Ljubljana: ZRC SAZU Anton Melik Geographical Institute.

Polainar Horvat K., 2015. Environmentally friendly behaviour. Ljubljana: Založba ZRC.

Pouıč M., 2002. Odnos do okolja, vedenjske in socialne pasti. Panika, vol. 7, no. 1, pp. 170-177.

Schlegelmilch B.B., Bohlen G.M., Diamantopoulso A., 1996. The link between green purchasing decisions and measures of environmental consciousness. European Journal of Marketing, vol. 30, no. 5, pp. 35-55.

SCHultz P.W., 2002. Knowledge, education, and household recycling: Examining the knowledgedeficit model of behaviour change [in:] T. Dietz, P.C. Stern (eds.), New tools for environmental protection, pp. 67-82, Washington D.C.: National Academy Press.

SCHWARTZ S.H., 1968. Words, deeds, and the perception of consequences and responsibility in action situations. Journal of Personality and Social Psychology, vol. 10, no. 3, pp. 232-242.

SCHWARTZ S.H., 1977. Normative influences on altruism. Advances in Experimental Social Psychology, 10, pp. 221-279.

SCHWARTZ S.H., 1992. Universals in the content and structure of values: Theoretic advances and empirical tests in 20 countries. Advances in Experimental Social Psychology, vol. 25, pp. 1-65.

SChWARTZ S.H., HOWARD J.A., 1984. Internalised values as moderators of altruism [in:] E. Staub,
D. Bar-Tal, J. Karylowski, J. Reykowski (eds.), Development and maintenance of prosocial behaviour, New York: Plenum Press, pp. 189-211.

SChWARTZ S.H., TeSSLER R.C., 1972. A test of a model for reducing measured attitude-behaviour inconsistencies. Journal of Personality and Social Psychology, vol., 24, no. 2, pp. 225-236.

SMREKAR A., 2011. From environmental awareness in word to environmental awareness in deed: The case of Ljubljana. Acta Geographica Slovenica, vol. 51, no. 2, pp. 277-292.

SmREKAR A., KLADNIK D., 2007. Zasebni vodnjaki in vrtine na območju Ljubljane. Geofitem, 4, Ljubljana: Založba ZRC.

Steg L., De Groot J.I.M., Dreijerink L., Abrahamse W., Siero F., 2011. General antecedents of personal norms, policy acceptability, and intentions: The role of values, worldviews, and environmental concern. Society and Natural Resources, vol. 24, no. 4, pp. 349-367.

Steg L., Dreijerink L., Abrahamse W., 2005. Factors influencing the acceptability of energy policies: A test of VBN theory. Journal of Environmental Psychology, vol. 25, pp. 415-425.

Steg L., Perlaviciute G., van den Verff E., LurVINK J., 2014. The significance of hedonic values for environmentally relevant attitudes, preferences, and actions. Environment and Behaviour, vol. 46, no. 2, pp. 163-192.

Steg L., VLeK C., 1997. The role of problem awareness in willingness-to-change car use and in evaluating relevant policy measures [in:] T. Rothengatter (eds.), Traffic and transport psychology: Theory and application, Oxford: Elsevier, pp. 465-475.

STĘPNIEWSKA M., 2015. Assessing the water footprint of national consumption for Poland. Geographia Polonica, vol. 88, no. 3, pp. 503-514.

STERN P.C., 2000. Toward a coherent theory of environmentally significant behaviour. Journal of Social Issues, vol. 56, no. 3, pp. 407-424.

Stern P.C., Dietz T., Abel T., Guagnano G.A., KaLOF L., 1999. A value-belief-norm theory of support for social movements: The case of environmental concern. Human Ecology Review, vol. 6, no. 2, pp. 81-97.

Stern P.C., Dietz T., Guagnano G.A., 1998. A brief inventory of values. Educational and Psychological Measurement, vol. 58, no. 6, pp. 984-1001. 
VAN DER PUtTE B., 1991. 20 years of the theory of reasoned action of Fishbein and Ajzen: A meta-analysis. Amsterdam: University of Amsterdam [Unpublished manuscript].

VINING J., EBREO A., 1990. What makes a recycler?: A comparison of recyclers and nonrecyclers. Environment and Behavior, vol. 22, no. 1, pp. 55-73.

Vlek C., Steg L., 2007. Human behaviour and environmental sustainability: Problems, driving forces and research topics. Journal of Social Issues, vol. 63, no. 1, pp. 1-19.

Urbanc M., Breg M., 2005. Gravel plains in urban areas: Gravel pits as an element of degraded landscapes. Acta Geographica Slovenica, vol. 45, no. 2, pp. 35-61.

ŽiBret M., 2009. Vrednote kot motiv družbeno odgovorne potrošnje: primer ekološke hrane. Ljubljana: University of Ljubljana [Master thesis]. 